23. Rodaway, P. (2006). Humanism and people-centred methods, in Aitken, $S$ \& Valentine, $G$ (eds), Approaches to human geography, SAGE Publications Ltd, London, pp. 263-272, viewed 3 March 2018, doi: 10.4135/9781446215432.n25.

24. Tardieu, P. (1852). Nouveau plan de la ville de Paris divisé en 12 arrondissemens et 48 quartiers [online]. Available throught Bibliothèque nationale de France (BnF): <http://gallica.bnf.fr/ark:/12148/btv1b530852613> [Accessed 3 March 2018].

25. Théâtre de George Sand: Claudie. Lucie. Lepressoir. Flaminio. [pdf] Paris: Collection Hetzel. 1860. 372 p. Available at:

$<$ https://books.google.com.ua/books?id=iX1KAQAAIAAJ\&printsec $=$ frontcover\&dq $=$ Théâtre + de + George + Sand $+\ldots .+$ Claudie.+ Lucie.+ Le + pressoir.+ Flaminio $\& h l=r u \&$ sa $=X \& v e d=0 a$ hUKEwj6sMCt56jZAhUCEVAKHYoqC7IQ6AEIJzAA\#v=onepage $\& q=$ Th\%C3\%A9\%C3\%A 2tre\%20de\%20George\%20Sand\%20...\%3A\%20Claudie.\%20Lucie.\%20Le\%20pressoir.\%20 Flaminio\&f $=$ false $>$ [Accessed 3 March 2018].

УДК $786.2+78.03+78.085 .21$

ORCID: 0000-0001-9139-2203

Инна Тимченко-Быхун, кандидат искусствоведения, доцент, заведующая кафедрой истории музыки Киевского института музыки им. Р. М. Глиэра, ул. Л. Толстого, 31, Киев, 01032, Украина

Inna Timchenko-Byhun, Ph.D. in Arts, Associate Professor, Head of the Department of Music History, R. Glier Kyiv Institute of music, 31 Lva Tolstogo St., Kyiv 01032, Ukraine

\title{
НОКТЮРН М. ГЛИНКИ ДЛЯ ФОРТЕПИАНО ИЛИ АРФЫ И ЕГО КУЛЬТУРНО-АВТОБИОГРАФИЧЕСКИЕ СМЫСЛЫ
}

Статья посвящена рассмотрению культурно-автобиографических смыслов Ноктюрна Es-dur М. Глинки (1828 г.) для фортепиано или арфы, изначально ориентированного на два инструмента. Анализ художественной мотивации такого композиторского решения позволяет осознать значение этого раннего сочинения в пианизме Глинки. Внимание сконцентрировано на каждом из трех смысловых маркеров названия сочинения: ноктюрн (как жанр пианизма Глинки) - арфа и ноктюрн - фортепиано и ноктюрн. Рассматривается значение жанра ноктюрна в пианизме Глинки, а также смыслы, связанные с его арфовой и фортепианной интерпретациями. Используются перспективный и ретроспективный векторы рассмотрения т.е., осмысление направленности композиторских поисков в конце 20-х годов, а также констатация принципов, которые сформировались в этом сочинении и впоследствии закрепились в фортепианном стиле Глинки. 
Ключевые слова: ноктюрн Глинки, романтическая образность, ноктюрновая образность, фортепианное исполнительство, арфовое исполнительство.

Ноктюрн М. Глінки для фортепіано або арфи та його культурноавтобіографічні смисли. Стаття присвячена розгляду культурноавтобіографічних смислів Ноктюрну Es-dur М. Глінки (1828 г.) для фортепіано або арфи, від початку орієнтованого на два інструменти. Аналіз художньої мотивації такого композиторського рішення дозволяє усвідомити значення цього раннього твору в піанізмі Глінки. Увагу сконцентровано на кожному 3 трьох смислових маркерів назви твору: ноктюрн (як жанр піанізму Глінки) - арфа і ноктюрн - фортепіано i ноктюрн. Розглядається значення жанру ноктюрну в піанізмі Глінки, а також смисли, пов'язані з його арфовою і фортепіанною інтерпретаціями. Використовуються перспективний і ретроспективний вектори розгляду тобто, осмислення спрямованості композиторських пошуків в кінці 20х років, а також констатація принципів, які сформувалися в цьому творі і згодом закріпилися в фортепіанному стилі Глінки.

Ключові слова: ноктюрн Глінки, романтична образність, ноктюрнова образність, фортепіанне виконавство, арфове виконавство.

Nocturne by M. Glinka for piano or harp and its cultural and autobiographical meanings. The article is devoted to the culturalautobiographical meanings of the Nocturne Es-dur by M. Glinka (1828) for piano or harp originally oriented to two instruments. An analysis of the artistic motivation of such a compositional solution makes it possible to understand the significance of this early work in Glinka's pianism. Attention is concentrated on each of the three semantic markers of the title of the composition: nocturne (as a genre of pianism by Glinka) - harp and nocturne - pianoforte and nocturne. The significance of the nocturne genre in the pianism of Glinka, as well as the meanings associated with his harp and piano interpretations are considered. Perspective and retrospective review vectors are used-that is, the comprehension of the direction of compositional searches in the late $1920 \mathrm{~s}$, as well as the statement of the principles that were formed in this work and subsequently consolidated in Glinka's piano style.

Key words: Glinka's nocturne, romantic figurativeness, nocturnal imagery, piano performance, harp performance. 
С человеком рифмуется вся природа. Й. В. Риттер

Ноктюрн для фортепиано или арфы Es-dur 1828 года - по сути, первая миниатюра ${ }^{1}$ М. Глинки. Произведение является не только самым популярным в раннем пианизме композитора, но и в равной степени востребованным как в фортепианном, так в арфовом репертуарах. Ноктюрн - первый фортепианный опус Глинки, оригинальный по музыкальному тематизму и свободный по выбору музыкальной формы-схемы. Ведь прежние его сочинения для фортепиано - вариационные циклы, почти все созданные на заимствованные темы, представляли собой развернутые построения с обязательным чередованием разнохарактерных вариаций, возникающих в диалоге с чужим музыкальным материалом. В этом смысле самостоятельность замысла ноктюрна - от круга образов до жанровой основы и типа структурной организации сочинения - вольное и невольное свидетельство значимых художественно-эстетических интересов и представлений композитора этих лет. Что подтверждается смысло-образностью пьесы просветленной пейзажно-созерцательной лирикой, впоследствии появляющейся в разнообразных жанровых синтезах в пианизме Глинки.

Ориентированность пьесы Глинки на специфику звучания двух инструментов - фортепиано или арфы - интересная особенность ноктюрна. Закончив Вариационный цикл на тему Моцарта для фортепиано или арфы, Глинка вскоре создает ноктюрн - одно из самых вдохновенных сочинений, собственный образец рафинированного инструментализма. Но - что удивительно, - найдя гармоничный сплав фортепианно-арфового звучания, композитор одновременно и завершает эту линию пианизма, чтобы к взаимозаменяемой паре инструментов и своеобразному типу фактуры, удобной для каждого из них, никогда больше не возвратиться. Просветленно-идиллические, ноктюрновые эпизоды будут появляться в более поздних фортепианных пьесах Глинки, но наполнятся уже не инструментальным, а вокально-кантиленным началом.

Дебют в жанре фортепианной миниатюры - весомый повод для пристального внимания исследователя. Тем более, если речь идет о значимой для композитора образности, о закономерностях его музыкального мышления, имевших развитие в более зрелом творчестве. И уж, конечно, если одно из использованных решений, напротив, не получило продолжения в дальнейшие годы.

\footnotetext{
1 К этому времени композитор написал для фортепиано 4 вариационных цикла. Французская кадриль, возможно, написанная в 1825-ом, была издана лишь в 1829-ом году, к которому обычно ее и относят.
} 
Обозначенные факты музыковедами, по сути, прокомментированы не были. В обращении к сформулированным вопросам состоят актуальность и новизна проблематики статьи. В связи с этим, цель статьи рассмотрение культурно-эстетических и автобиографических смыслов изначально ориентированного на два инструмента Ноктюрна Es-dur, a также поиск художественной мотивации такого решения. Для этого внимание сконцентрировано на каждом из трех смысловых маркеров сочинения: ноктюрн - арфа - фортепиано. При этом рассматривается значение жанра ноктюрна в пианизме Глинки, а также смыслы, связанные с его арфовой и фортепианной интерпретациями, что входит в задачи статьи. Используются перспективный и ретроспективный векторы рассмотрения: осмысление направленности композиторских поисков в конце 20-х годов и констатация принципов, сформировавшихся в этом сочинении и впоследствии закрепившихся в фортепианном стиле Глинки. Применяются принципы культурологического комментария, разработанного в музыковедении С. Тышко и С. Мамаевым, а впоследствии С. Тышко и Г. Куколь, при котором факты творческой биографии и события личной судьбы композитора рассматриваются в неразрывной связи.

1. Ноктюрн - особый жанр в инструментализме Глинки. Ноктюрновость - как семантическое единство смысло-образа и присущих ему средств музыкальной выразительности - будет впоследствии возникать во многих инструментальных сочинениях композитора. О первом фортепианном ноктюрне Глинки в музыковедческой литературе есть отдельные замечания: ни в монографии Т. Ливановой и В. Протопопова, ни в книге О. Левашевой, миниатюра практически не рассматривается. Значительно более подробно ноктюрн Глинки исследует К. Зенкин, называя его «инструментальным аналогом песенно-романсовой сфере» и справедливо отмечая черты родства пьес этого жанра Глинки и Шопена - фильдовским [9, c. 262]. Действительно, жанровый инвариант, изобретенный Дж. Фильдом, оказался уникально созвучным культурным ожиданиям его времени, явился одним из самых востребованных изобретений романтического инструментализма, соединив новый комплекс музыкальных средств выражения с лирическими пейзажными смысло-образами, значимыми для романтической культуры: образами ночи, таинственной тишины, природы, любовного томления, созерцательности.

Образность глинкинского ноктюрна - своеобразная квинтэссенция различных граней лирического мироощущения молодого композитора. Ноктюрн синтезирует черты классицистского и романтического типов трактовки формы. Соответствие классическому сонатному Andante без 
разработки позволяет композитору, опирающемуся на традиционный тональный план, достаточно свободно выстроить форму ноктюрна. Возможно, однако, рассматривать ноктюрн и с точки зрения характерной для романтической миниатюры простой трехчастной репризной формы. Тогда в одном из самых ранних сочинений Глинки можно заметить необычные особенности трактовки формы; вообще нарушения традиционной структуры, при которых она одновременно тяготеет к разным типам композиции, станут одной из характерных черт стиля Глинки. Так, если исходить из идеи трехчастности, то повтор темы среднего раздела после репризного проведения первой, создает двойственное ощущение трехчастности и двухчастности (ABA1B1); эту часть композиции можно трактовать как весьма развернутую коду, построенную на материале середины, что обозначается схемой: ABA + кода (на материале В). Тем более что тяготение к типу строения сочинений с развернутыми кодами - одна из характерных черт индивидуального мышления Глинки первого периода, это заметно во многих вариационных циклах, в том числе и более поздних лет.

Еще одной характерной особенностью глинкинской трактовки формы является обострение контраста тематизма частей при общем сохранении единства лирической образности. Контраст в данном случае создается посредством сопоставления различной интонационно-жанровой основы двух тем первого раздела и материала лирической середины: первой - романсовой, ноктюрновой, кантиленной, второй - просветленно-меланхоличной и прелюдийной, как бы возникающей из фигураций, с чертами созерцательности и размытыми границами между фразами. Найденный в этом сочинении прием усиления контраста между темами, создаваемый больше интонационными, чем образными средствами, впоследствии обретет статус одной из характерных черт глинкинского инструментального стиля.

Мелодика основной темы ноктюрна - романсовой, вокальной природы, - охватывает широкий диапазон (фа первой октавы - ми третьей). Ее жанрово-интонационную романсовую основу подтверждает и аккомпанемент в виде разложенных арпеджио, движущихся по звукам аккорда триолями в восходящем и нисходящем направлениях в четырехдольном размере. Арпеджированный тип аккомпанемента, охватывающий преимущественно аккордовые звуки, является знаком ранних романсов Глинки, в том числе и написанных в 1828 году («Куда ни взгляну», «Как в вольных просторах», «Если вдруг средь радостей»), встречаясь в разных метроритмических и интонационных условиях и в более поздние годы. Е. Браудо отмечает общую тенденцию: 
инструментальная музыка немецких романтиков «обнаруживает сильное тяготение к романсу - так складывается типичная мендельсоновская ,песня без слов"» [2].

Триольность аккомпанемента в размере 4/4, создающая полиритмию пластов мелодии и сопровождения, в сочетании с иными средствами музыкальной выразительности, дополняет материал первой части ноктюрна признаками еще одного жанра - баркаролы. Существенно, что уже в эти годы Глинка использует жанровое сочетание черт ноктюрна и баркаролы, что впоследствии проявится в его сочинениях разных жанровых сфер (в романсе «Венецианская ночь» 1833 г., фортепианной «Баркароле» 1847 г., где баркарола обретет характерные черты глинкинского ноктюрна). Здесь баркарольность создается триольным аккомпанементом, плавным движением мелодии, ритмической монотонностью сопровождения, как бы имитирующей плеск волн и движение весел, а также характером музыкального материала, который в баркароле чаще всего «лирический, нередко с оттенком меланхолии или светлой мечтательности» [5]. Ритмический рисунок аккомпанемента первой темы неизменен на протяжении 17 тактов. В подобном единстве «мелодического дыхания» и сохранении «фактурного рисунка» главной темы проявляется «цельность эмоций» [9, с. 262]. Однако, как видим, графическое постоянство фактуры напрямую связано и с ощутимой в ней баркарольной природой ${ }^{1}$.

Вторая тема первой части - побочная (Си бемоль мажор - соль минор) интонационно вырастает из первой, но представляет собой вопросо-ответную структуру - после двухтактовой вопросительной интонации, изложенной аккордами на $f$, следует ответ: нисходящие пассажи. Эта тема содержит в себе разнообразные в ритмическом отношении мотивы; являясь контрастной по отношению к первой, она не создает принципиально нового настроения.

Тема среднего раздела, или заключительной партии, близка прелюдии. В ней есть черты этюдности, лирической моторики. Именно этот раздел формы представляет собой наибольший аналитический интерес. Тем более что это построение завершает миниатюру, появляясь в репризе в основной тональности. Тема (модулирующая из соль минора в Ми бемоль мажор) представляет собой музыкальный материал,

\footnotetext{
${ }^{1}$ Интересно, что баркарольность оказывает опосредованное влияние и на мелодическую линию основной темы, что выражено в ее рисунке более крупного плана: она также содержит в себе скрытое покачивание - графически мелодия соответствует волнообразной линии, меняющей свое направление каждые полтакта.
} 
изложенный фигурационно и лишенный выраженной мелодической линии. Ритмическая остинатность темы присуща материалу правой руки, изложенному группами шестнадцатых длительностей. Условная мелодическая линия, перенесенная в левую руку, также, представляя собой остинатное движение восьмыми на сильные доли такта (первая дважды повторенная фраза - опевание тонического звука, тоника и третья ступень), постепенно расширяет свой диапазон, но в целом, является одним из пластов фактуры. К. Зенкин замечает: «Заключительная тема дает еще один пример раннеромантического звукоощущения: это «тончайшая» фигурационно-прелюдийная ткань совсем без мелодического голоса, одновременно как бы «баховская» и «шумановская»» [9, с. 262].

Интонационно-жанровой основой этой темы становится прелюдийность - способ изложения музыкальной ткани, основанный на безостановочном движении. Прелюдийность, реализованная таким сочетанием средств, больше не появится в фортепианной музыке Глинки. Позднее черты прелюдирования всегда будут подчинены воздействию какого-либо иного интонационно-жанрового начала, например, танцевального, или этюдного, выступать в синтезе с ним. В «Прощальном вальсе» (1831 г.) прелюдийность соединится с вальсовым началом, станет его неотъемлемой частью, вторым жанровым знаком, при котором можно трактовать сочинение как вальс с чертами прелюдии, и почти в равной степени как романтическую прелюдию с чертами вальса. Тончайшая звуковая ткань этого раздела ноктюрна обретает статус пространственнооформленной звуковой среды, что усиливается в исполнении ноктюрна на арфе, но ощутимо и в ориентированной на прозрачность звучания арфы игре пианиста. Ее невесомость, воздушность, почти бесплотность, будто передает само невидимое движение воздушных сфер ${ }^{1}$.

\section{2. Арфа и ноктюрн.}

Арфа обрела у романтиков новое звучание - именно она оказалась способной воссоздавать самые утонченные смыслы романтической образности, в которой струны арфы и струны души обретали созвучность, не требующую расшифровки. Н. Покровская замечает: «Для романтиков арфа стала инструментом, олицетворявшим народное творчество, фантастический мир и древние мистерии. Поэтому к ней обращались

\footnotetext{
${ }^{1}$ В утверждении подобного взгляда на мир очевидно влияние немецкого романтизма: «Идея единства любви, природы, красоты, творчества является центральной в произведении Новалиса „Голубой цветок”» [19]. «У Кольриджа ... тема природы тесно переплетается с темой любви, красоты, радости - в данном видении Кольриджем природы можно усмотреть влияние немецкого романтизма - Шеллинга и Новалиса» [19].
} 
Я. Л. Дусик， Л. Шпор， Л. Бетховен， Э. Гофман， Г. Берлиоз， А. Буальдьё, О. Козловский, А. Верстовский, М. Глинка» [18]. «...Я тогда в первый раз познакомился с арфою - прелестным инструментом, если его употреблять вовремя», - замечает в «Записках» композитор. Так он вспоминает период ранней весны 1822 года - знакомство и общение с арфисткойлюбительницей, «молодой барыней красивой наружности», которая произвела на 17-летнего юношу сильное впечатление хорошей игрой на арфе и «прелестным сопрано» $[4$, c. 221]. Это был последний год пребывания Глинки в Благородной пансионе; стоит ли удивляться, что Михаил, очарованный талантливой, красивой и обаятельной молодой женщиной, предпочитал учебе, по его собственному выражению, «поэтическое препровождение времени» [4, с. 221]? Мы приводим многократно процитированные в литературе слова Глинки лишь потому, что более поздние замысел и образность ноктюрна с такой очевидностью связаны с этим ранним впечатлением, - несмотря на хронологический разрыв в шесть лет, - что это почти не требует доказательств.

Восхищение арфисткой оказалось столь сильным, что даже через тридцать лет композитор эмоционален: «Голос ее не походил ни на какой другой инструмент, это был настоящий звонкий серебряный сопрано», «она пела естественно и чрезвычайно мило». «Ее прекрасные качества и ласковое со мной обращение $<\ldots>$ расшевелили мое сердце и воодушевили мое воображение», «она любила музыку», «подпевала нам в любимых ею местах своим звонко-серебряным голосом» - мало кто даже из известных музыкантов удостоился столь лестных слов Глинки [4, с. 220-221]. Известно, как велика была «роль любительства в России при становлении исполнительской школы игры на арфе», что особо подчеркивает Н. Покровская [18]. Кроме того, отметим и наличие своеобразной моды на арфу в 20-е годы XIX века в Москве, о чем, в частности, пишет Н. Финдейзен [цит. по: 18]. Эти впечатления Глинки составляют внешний, наиболее очевидный уровень причин его интереса к арфе. Тогда для арфистки им были написаны Вариации на тему из оперы Вейгля «Швейцарское семейство» (текст не сохранился) и, следом, Вариации на тему Моцарта ${ }^{1}$ - первые

\footnotetext{
1 Интересные сведения «о связи Глинки с современной и предшествующей ему музыкальной культурой» арфового исполнительства приводит Н. Покровская: «Вариации на тему Моцарта из сцены Мистерий Изиды в опере «Волшебная флейта» («колокольчики Папагено») встречаются раньше всего в Школе П. Ж. Кузино, затем в «Принципах» И. М. Плана, Школе К. Дезаргю с аккомпанементом из тройных флажолетов в левой руке, в «Попурри» М. Дальвимара и, наконец, в раннем опусе Глинки «Вариациях на тему Моцарта», написанном для арфистки-любительницы в
} 
парафразы композитора [4, с. 221]. Казалось бы, авторский замысел взаимозаменяемости инструментов исчерпывающе объясняется историкокультурными причинами общего характера ${ }^{1}-$ К. Зенкин по этому поводу пишет: «В русской музыке еще не успели откристаллизоваться формы самобытного национального инструментализма» $\left[9\right.$, с. 260] ${ }^{2}$. Согласимся с этим - но пойдем в рассуждениях далее.

Почему Глинка вновь обращается к звучанию арфы соло через шесть лет? Ответ прост - в основе его аргументы, приведенные Н. Загорным о времени написания Вариаций: «в творческой практике Глинки многочисленны случаи сочинения музыки без немедленной фиксации ее на бумаге... Именно таким представляется нам случай с Вариациями на тему Моцарта, которые были, очевидно, сочинены и игрались Глинкой в 1822 г., записаны же (вероятно, и выписаны в деталях) в 1827 г.) [8, с. 418]. А завершая в записи прежнее сочинение, композитор мог вновь вдохновиться звучанием покорившего его инструмента.

Ориентированность на два инструмента, арфу и фортепиано, является детерминирующим условием для сочинения, ведь арфа в большей степени, чем фортепиано, диктует особенности музыкального языка, одновременно не только открывая специфические тембральные красочные возможности, но и определяя ограничения в фактуре, мелодике, даже в выборе тональностей ${ }^{3}$.

Арфа считается одним из самых сложных для исполнителя инструментов. Ее специфика требует учета целого ряда факторов. «Звучание арфы, достаточно звонкое и сильное, не обладает способностью к протяжным

1822 г. Можно ли считать случайным обращение Глинки именно к данной теме, уже известной в России из арфовых сочинений европейских авторов? По-видимому, выбор был подсказан знакомством с репертуаром, широко играемым в среде аматёров. Обработки «Камаринской», также связанной в нашем сознании с творчеством великого композитора, были известны русским и французским арфистам еще с 1797 г. и из «Принципов» Плана, изданных на рубеже XVIII и XIX веков» [18]. При этом автор подчеркивает, что «влияние парижской школы игры на русскую можно видеть лишь в области фактуры: «ее типичности и удобстве», тогда как «в смысле же художественной ценности арфовых опусов Глинки, Девитте и их европейских коллег, то сравнение не в пользу последних», поскольку заимствованные темы разработаны «у Глинки и Девитте гораздо богаче и разнообразнее» [18].

1 Такой авторский замысел мог быть связан с практическими задачами: известно, что при отсутствии фортепиано, часть фортепианного репертуара этого времени могла быть исполнена на арфе или гуслях (об этом пишут С. Тышко и С. Мамаев: [27, с. 144]). 2 «Отдав дань «блестящему стилю» в творчестве выдающихся виртуозов Ш. Бокса и Э. Пэриш-Альварса, арфа в середине XIX века переходит в салон и надолго там остается» [18]. ${ }^{3}$ Известно, например, что для арфы предпочтительны бемольные тональности. 
мелодиям. Мелодические построения, умеренно активные по своей фактуре, в то же время не должны иметь слишком много нот», - замечает, например, современный исследователь Пистон Уолтер [17, с. 311]. Зато в исполнении удобных фактурных рисунков арфа не имеет себе равных по красоте и нежности звучания: «Арфа представляет собой инструмент, более приспособленный к выполнению гармонических аккордов, разного рода фигураций, а также декоративных эффектов типа glissando, чем мелодических рисунков или сложных чеканных пассажей» [29, с. 152]; или: «Превосходно получаются арпеджио, как ломаные, так и через весь диапазон инструмента...» [29, с. 151], кроме того: «Возможность дать звуку свободно вибрировать вполне соответствует природе инструмента» [17, с. 309].

Названные особенности учтены Глинкой при сочинении ноктюрна, что свидетельствует о тщательной проработке деталей и понимании специфики арфы. Композитор не случайно избирает средний (ре малой - ре второй октавы) - «полнозвучный и мягкий» и высокий регистры (соль второй - соль третьей октавы) - «звонкий и светлый» [29, с. 150]. Хорошо известно, что именно эти регистры для арфиста являются наиболее выигрышными. Одновременно с тем, данное соединение тембра и регистра соотносится с образом-настроением инструментального ноктюрна как жанра, созданного раннеромантическим фильдовским пианизмом - возвышенноодухотворенного, юношески-мечтательного, утонченно-лирического.

Добавим, что подобная романтическая семантика оказалась столь прочно связанной со звучанием арфы, что даже в XX веке потребовала специальных мер по ее преодолению, в том числе и в массиве оркестра: «Некоторые композиторы XX века оказали предпочтение применению фортепиано вместо арфы, полагая, вероятно, что последняя вызывает определенные романтически ассоциации, которых они хотели избежать» ${ }^{1}$ $[17$, с. 318$]$. Вообще же, арфа сыграла особую роль «в романтическом искусстве Европы конца XVIII-начала XIX вв., ставшем основой для развития национальных исполнительских школ» [18].

В результате, создав два сочинения для арфы соло, Глинка в последующие годы использовал этот инструмент лишь в составе камерных ансамблей и оркестра. Очевидно, это связано с исчерпанностью им еще в раннем творчестве такого синтеза образности - и специфических качеств звучания инструмента. Это обусловлено и формированием иных задач, требовавших поиска новых тембральных средств и новых интонационно-

1 Глинка в «Записках по инструментовке» замечает по поводу «прибавочных инструментов», среди которых и арфа, что они «оставляют роскошь оркестра, т.е. могут и должны быть употребляемы в особенных случаях, в виде исключения...» [4, с. 181]. 
жанровых сочетаний. Ведь, если Вариационный цикл на тему Моцарта, все же, в большей степени был предназначен для арфы - именно она в полной мере способна была передать воздушность и невесомость звучания музыкальной ткани сочинения ${ }^{1}-$ то ноктюрн ориентировался преимущественно на фортепиано. Но - на тот специфический тип пианизма, в котором присутствовала бы память звучания арфы.

Первый романс Глинки на слова К. А. Бахтурина был написан в 1824 году и назывался «Моя арфа». Опоэтизированный романтиками инструмент в этом стихотворении метафорически отображает саму музыку: «Я всем пожертвовал тебе, сердец очарованье, моя арфа!» Символ музыки, которой всецело отдан лирический герой - это одновременно и образ высокого идеала, самого центра художественного мира романтического творца, невыразимый словами, но угадываемый в поэтической символике недосказанности. Стоит ли удивляться, что возвышенно-поэтические настроения, связанные с представлениями о возникновении музыки из тишины звучащей природы, воплотились композитором в жанре ноктюрна? Однако, именно арфа, ее звуковая - и шире, культурно-эстетическая семантика, - оказывается ключом для понимания романтического образа среднего раздела ноктюрна Глинки.

Образ Эоловой арфы, символического соединения природы, а в представлениях романтизма, мировой души - и музыки, будто порождаемой самим дыханием мироздания, становится одним их многозначных художественных знаков, культурных образов, одновременно идущих из воспеваемой древности и создаваемых романтической культурой заново. Нет сомнений, что прелюдийная ткань средней части глинкинского ноктюрна, звуковая среда, лишенная мелодической материализации, созвучна образу романтической Эоловой арфы. В эти годы Глинка общался с литературнопоэтической элитой своего времени, и, по воспоминаниям современников,

\footnotetext{
${ }^{1}$ Н. Зимин приводит интересные сведения: «В 30-х годах XIX века Шредера взял под свое покровительство известный в то время журналист Фаддей Булгарин, одобривший его новое изобретение - арфу, «перерезанную поперек фортепианами». Он писал об этом инструменте так: «Вы слышите звук арфы и между тем играете по клавишам. Польза изобретения Шредера также очевидна: на его инструменте играть несравненно легче и приятнее, чем на арфе и притом не нужно учиться особо: довольно уметь играть на фортепиано». По-видимому, речь шла об инструменте типа клавиарфы, которая была в то время распространена за границей. Булгарин указывает и адрес Шредера: «В Малой Садовой, в доме купца Куприянова №20». В настоящее время трудно судить, был ли это тот Шредер, который с 1818 года имел свою фабрику на углу Казанской и Вознесенской улиц, а позднее на Петербургской стороне, или же это был один из его однофамильцев» [10].
} 
хорошо знал поэзию, пробовал и свои силы в сочинительстве. Так, Н. Маркевич подчеркивал, что Глинка «был хорошим оценщиком поэзии» [цит по: 14, с. 44]. Естественно увидеть здесь влияние на композитора образов поэзии, в том числе русской, во многом в те годы ориентированной на антологическую лирику (с ее идиллически-пейзажной образностью).

Арфа, один из древнейших инструментов, отзывается в русской культуре этого времени смыслами, имеющими истоки в древнегреческих представлениях о мире. «Арфа - древнейший музыкальный струнный щипковый инструмент. Символ связи неба и земли, символ мистической лестницы. Воплощение чистой идеи звука: Эолова арфа - инструмент, на котором играет ветер» [33, с. 480]. В древнегреческих представлениях арфа была атрибутом греческой музы песни и танца Терпсихоры. С ней связано много культурных и художественных смыслов: «Как и лира, арфа символизирует в соответствии с пифагорейской философией мировую гармонию. Она являет собой мост между небом и землей. Ее форма мистическая звуковая лестница, соединяющая горний и дольний миры» ${ }^{1}$ [11].

Романтические художники подчиняют древние культурные образы собственным, индивидуальным представлениям о мире - романтизм наполняет их новыми интенциями, понятными и близкими своему времени и своей культуре. В то же время каждый художник претворяет их индивидуализированно, расширяя, дополняя и раздвигая смысловые границы. Дух Эоловой арфы - образа, претворенного русской поэзией в романтическом ключе, в первую очередь, конечно, В. Жуковским ${ }^{2}$

\footnotetext{
${ }^{1}$ И далее: «Арфа также является атрибутом царя Давида: через символику десяти струн Давидовой арфы святой Августин разъяснял смысл десяти заповедей. По арфе имели каждый из 24 старцев, упоминаемых в Апокалипсисе. Арфа также символизирует циклическое развитие мира. Кельтский бог изобилия Цернун производил смену времен года посредством игры на этом музыкальном инструменте. В скандинавской мифологии предстает как образ моста между двумя мирами. Согласно Эдде, погибших погребали вместе с их арфами, чтобы тем самым облегчить им путь в иной мир. Также наделяется функцией миросотворения, подобно другим музыкальным инструментам. В кельтской мифологии бог Дагда играет на арфе-дубе, и в соответствии с характером его игры свершается смена времен года. Аналогично другим струнным инструментам (струны которых могут быть уподоблены человеку, его страстям), арфа также выступает в качестве символа мистического напряжения и стремления к трансцендентному» [11].

${ }^{2}$ В переводах В. Жуковского встречаются отголоски образа арфы как одного из голосов самой природы. Так, в переводе стихотворения «Элизиум» Маттисона есть строки о шепоте в лесу, который «Как струи ленивой ропот, / Как воздушной арфы звон...» [1, c. 275]. Маттисон написал стихотворение в 1789 г., в его основе - античный миф о Психее в обители мертвых, обретающей забвение земных страданий. Шиллер назвал поэта «апостолом истинной красоты»- указывает С. Аверинцев в примечании [1, с.
} 
(знаменитая поэма «Эолова арфа» 1814 г., исполненная и идиллических, и элегических мотивов), витает над ноктюрном Глинки. Эта связь - не внешнего, а внутреннего уровня взаимовлияний разных видов искусств - тем более объяснима, поскольку известно, что Глинка увлекался поэзией Жуковского в 20-е годы.

В Энциклопедическом словаре Ф. А. Брокгауза и И. А. Ефрона приводятся сведения: «Эолова арфа - музыкальный инструмент, состоящий из деревянного ящика, в котором натянуты струны (от 8 до 12). От движения воздуха струны издают разные гармоничные созвучия, таинственного, нежного характера. Берлиоз в своем инструментальном сочинении: „Эолова арфа" изобразил оркестром в художественной форме поэтичные звуки Э. арфы. ...Этот инструмент получил свое название от Эола, мифологического бога ветров» [32]. Романтизм многократно претворяет образ арфы Эола ${ }^{1}$ в разных видах искусства; авторы книги о Глинке С. Тышко и С. Мамаев подчеркивают: «Симптоматичен подчеркнутый интерес романтиков к эоловой арфе как к инструменту природы, восхищавшему капельмейстера Крейслера (сам Крейслер описывает ее - «струны, натянутые над бассейном», т.е. над любой полостью-резонатором: над дуплом, в окне чердака и т.п.). Кстати, Глинка вполне мог слышать эолову арфу на Украине например, в доме Маркевича ${ }^{2} »[28$, с. 22].

Образ Эоловой арфы становится значимым для романтизма ${ }^{3}$ это своеобразный символ гармонии человека и двух миров - небесного и земного. В предисловии к «Фаусту» Гете использует этот образ, однако, не в идиллическом, а в драматическом ключе; на фоне традиционного противопоставления нынешнего - прошлого, «нахлынувшие извне» образы

589]. А вот еще аллюзии: друг Жуковского, А. Тургенев, писал о М. Н. Свечиной, которой был увлечен: «но муж и она - два инструмента совсем на разных тонах: он балалайка, может быть, очень стройная и звонкая, она арфа» [3].

1 Лирическую монодраму Г. Берлиоза «Лелио, или Возвращение к жизни», в которой появляется образ эоловой арфы, И. Соллертинский называет продолжением «Фантастической симфонии», «в высшей степени эксцентричным произведением», «литературно-музыкальным монтажем», где использованы музыкальные номера, сочиненные раньше, в частности, «коротенький оркестровый отрывок, озаглавленный «Эолова арфа» (взят из кантаты 1827 года «Орфей»...)...» [21, с. 214].

2 «...Эоловы арфы между зубцами на башне «оригинального, каменного дома» Маркевича, которые «на других наводили уныние своими фантастическими аккордами» [28, с. 134].

3 Ж. Жубер в 1815 году записывает в дневник: «Не стану отрицать, я похож на эолову арфу, которая издает несколько прекрасных звуков, но не исполняет никакой мелодии» [34, c. 371]. 
передаются рыданием Эоловой арфы. В лирике Кольриджа образ Эоловой арфы резонирует с меняющимися художественными взглядами поэта: «В первоначальном коротком варианте „Эоловой Арфы” 1795 года перед нами великолепный образец любовной лирики, где любовь созвучна отношениям ветра и струнам арфы. В версии 1796 года оно переросло в произведение о браке и о природе, ,all of animated nature”. В окончательной версии это все еще стихотворение о любви, космической любви, в котором любовь между поэтом и Сарой становится мостиком и объяснением отношений во вселенной - единения человека со вселенной, которое происходит, по словам Кольриджа, через любовь» [19].

В знаменитой поэме Жуковского древний образ пересматривается, облекается в ризу романтической тематики. Эолова арфа - символ любви, верности, невидимой связи миров земного и небесного: арфа, оставленная отправленным в изгнание юношей-певцом в утешение возлюбленной Минване, молчит. Она начинает звучать лишь после его смерти - когда его душа прилетает к ней. Жуковский снимает возникающее смысловое противоречие: древнегреческий исполнитель на арфе не земной человек, но ветер, движение воздуха; слившись с потусторонним миром, силами природы, ветром, душа юноши может перебором струн утешить возлюбленную. После ее смерти они оба становятся летящими в небе тенями: ветвистый дуб, символ вертикали между небесами и землей, и арфа, символ самой природы музыки, звучащей между пространствами, соединяют оба мира ${ }^{1}$. Самозабвенное увлечение поэзией Жуковского было присуще поколению Глинки. Вот что об этом писал В. Одоевский: «Мы теснились вокруг дерновой скамейки, где каждый по очереди прочитывал Людмилу, Эолову арфу, Певца в стане русских воинов, Теона и Эсхина; в трепете, едва переводя дыхание мы ловили каждое слово, заставляли повторять целые строфы, целые страницы... Стихи Жуковского были для нас не только стихами, но было что-то другое под звучной речью» [Цит по: 30, с. 234]. И Глинка признавался: «Сентиментальная поэзия Жуковского мне чрезвычайно нравилась и трогала меня до слез» [4, с. 231].

\footnotetext{
${ }^{1}$ В русской литературе отзвуки этого образа будут появляться и позже, на протяжении всего века. Так, в фантастической повести И. Тургенева «Призраки», содержащей некоторые аллюзии к стихотворению Жуковского, герой встречается с женщиной - таинственным призраком под старым дубом. Они становятся тенями, летящими в ночи - Эолова арфа выступает знаком страны-легенды, красоты природы: «Мне чудятся другие звуки, длинные, томные, подобные звукам эоловой арфы... Вот она, страна легенд! ...Воздух струится мягко и легко. Мне самому легко и как-то возвышенно спокойно и грустно...» [26].
} 
Эолова арфа как образ становится то символом, то литературной метафорой ${ }^{1}$, то используется в качестве прозвища. В этом смысле сложно даже пытаться обозначить весь спектр литературных и поэтических аллюзий романтизма, резонирующих с образом арфы Эола, равно как и ставить перед собой задачи охватить диапазон смысловых границ этого образа, символизирующего то голоса природы ${ }^{2}$, то пение самой мировой души. Цепляясь друг за друга как звенья одной цепи, подобно обертонам звучащих струн, образы русской и европейской романтической культуры разворачиваются в обратной временной проекции множественными смыслами, одновременно отзываясь и бесчисленными аллюзиями в своем времени; так возникают перекрестки смысловых, и даже текстовых пересечений. Образы глинкинского ноктюрна овеяны многозначными поэтическими смыслами его времени; однако «глинкинский Элизий» идилличен, едва осязаем, не материализован - образы культуры витают над музыкальным текстом, но остаются в области недосказанного. Глинка создает в раннем фортепианном сочинении идиллически-просветленную образность, формирует жанрово-интонационные средства ее выражения, которые впоследствии становятся знаками подобных настроений в его музыке.

С 1833 года ноктюрновая образность сочинений Глинки окрасится элегическими настроениями - например, в Вариациях на тему «Соловей», и в первоначальном виде уже никогда не появится. Подобно тому, как

1 Интересные сведения по поводу обыгрывания культурных образов членами литературного кружка «Арзамас» приводит Н. Яковкина: «В «Арзамас» вошли лица сугубо частные, имена их признавались несущественными и взамен давались прозвища: сам Жуковский, избранный секретарем общества, был наречен Светланой, А. Тургенев получил имя Эолова арфа, серьезный сдержанный Дашков был прозван Чу (предостерегающее междометие), пылкий и темпераментный Блудов - Кассандрой, Вигель за характерный острый профиль получил прозвище Ивиков журавль и т. п.». [35]. Не менее интересны слова Р. Шумана, который, восхищаясь игрой Ф. Шопена, писал: «Представьте себе, что эолова арфа обладает всеми тональностями, что рука артиста перемешивает их во всевозможных фантастических украшениях, но только так, что всегда слышен глубокий основной звук и мягко-певучий верхний голос. ...После исполнения этюда испытываешь настроение, точно только что увидал во сне чудную картину, которую вновь пытаешься уловить наяву» [2, с. 221-222].

2 Природа, становящаяся в романтических представлениях «живой, творящей» (высказывание Шеллинга), в произведения искусства обретает разные оттенки смыслов. «По Шеллингу, поскольку природа одухотворена, то душа человека также является ее порождением. Между природой и человеком существует глубокая внутренняя взаимосвязь: космос природы одухотворен, а человеческая душа космична в своей бесконечности. Отсюда проистекает глубокое внутреннее сродство между человеком и природой» [12]. 
элизийские идиллические батюшковские мотивы поэзии 1810-х годов окрасятся элегическими чертами, а с 1820-х годов и вовсе станут достоянием жанра элегии, трансформировавшись в ностальгическое представление о прекрасном ушедшем. В отличие от элегической сферы, которая в фортепианной музыке Глинки постепенно вытеснит ноктюрновую, окрасив лирику чертами печали и драматической безысходности, ноктюрновая образность формируется в музыке Глинки не в связи со словом, и не от слова. Ноктюрновые настроения отчасти возникают в романсах 1828 года, но набор средств музыкальной выразительности оттачивается в Ноктюрне.

Добавим, что семантика тональностей впоследствии будет значима именно в сфере ноктюрново-романсовой лирики Глинки ${ }^{1}$. Бемольные (арфовые) тональности Es-dur и As-dur окажутся связанными с кругом просветленно-идиллической образности, дополняясь в годы итальянского путешествия настроениями восторженного упоения, любования и радости жизни. В творчестве Глинки ранних и зрелых лет они станут знаком романтического гедонизма, а с конца 1840-х годов - идеализированного прошлого, окрашиваясь элегически-ностальгическим флером, что свидетельствует о присутствии прежних сочинений ноктюрнового настроения, как бы в симультанности, в памяти композитора.

\section{3. Фортепиано и ноктюрн.}

Не подлежит сомнению, что фортепианный ноктюрн создавался Глинкой под сильным впечатлением от ноктюрнов Фильда и его игры. Фильдовская

\footnotetext{
${ }^{1}$ В этой тональности написаны Вариации на тему Моцарта просветленно-лирического настроения (1822-1827), Большой секстет (1832), единственное сочинение итальянских лет, в котором в полной мере выразилась романтическая образность поэтического любования природой, восторженной радости, т.е. столь желанной для композитора гармонии внешнего и внутреннего миров. Семантически близок Ми бемоль мажору - Ля бемоль мажор: вспомним Ля бемоль мажорную вариацию Вариационного цикла на тему Беллини из оперы «Монтекки и Капулети», находящуюся в далекой степени родства по отношению к основной тональности цикла До мажор, - один из самых ярких образцов глинкинской ноктюрновой созерцательно-просветленной лирики в фортепианной музыке раннего, дооперного периода, или среднюю часть фа минорного Ноктюрна «Разлука», с ее отголосками созерцательно-просветленного настроения.

Вообще тональности с несколькими бемолями в фортепианной музыке Глинки часто становятся знаком лирических настроений, минорные - с оттенком грусти: так, уже в Вариациях на оригинальную тему, лирический центр Adagio cantabile molto espressivo написан в фа миноре; эта тональность является основной и для Ноктюрна «Разлука». А в одном из поздних сочинений, Баркароле, фактически завершающей его линию фортепианной лирики и построенной на образах воспоминаний об Италии, вторая тема, несмотря на ключевые знаки Ми бемоль мажора, по сути, звучит в одноименном миноре.
} 
манера звукоизвлечения, как известно, всегда оставалась для Глинки своего рода эталоном, образцом сочетания мягкости и отчетливости звучания. Необходимо заметить, что именно арфа, учитывая ее характерные особенности звукоизвлечения, могла воссоздать звучание, максимально приближенное к фильдовскому фортепианному туше: сочетание воздушности, легкости и мягкости, певучести, и в то же время отчетливости и ясности каждого звука. Сам Глинка об игре Фильда замечает: «До сих пор помню его сильную, мягкую и отчетливую игру. Казалось, что он не ударял по клавишам, а сами пальцы падали на них, подобно крупным каплям дождя, и рассыпались жемчугом по бархату» [4, с. 218]. Интересно, что, описывая исполнительскую манеру Гуммеля, близкую фильдовской, Глинка практически повторяется: «играл мягко, отчетливо» [4, с. 220]. И уж совсем неслучайно в этом ряду появление замечания Глинки об игре арфиста Н. П. Девитте, приехавшего из Москвы в 1843 году: «ОН играл очень отчетливо» [4, с. 112]. Уже сам авторский выбор инструментов - фортепиано или арфа - настраивал исполнителя на необходимый тип пианизма, формировал требуемые интерпретационные условия. Именно арфа могла воспроизвести ожидаемую композитором исполнительскую манеру, ориентированную на Фильда ${ }^{1}$ и его преемников; фортепиано, будто имитирующее арфу, сочетало тем самым отчетливость и мягкость, создавая воздушную пространственность звучания. Ведь черты ноктюрна Глинки - мелодическая плавность, певучесть, преобладание мажора, приглушенность динамики, триольность (12/8, 3/8 6/8) арпеджированного аккомпанемента, создающего звучащий фон и подчеркивающего мелодическую линию, - были присущи и фильдовским ${ }^{2}$.

Ориентация на подобный тип пианизма будет заметна и в итальянских сочинениях Глинки 30-х годов. Здесь они дополнятся новым

\footnotetext{
1 Фильдовская манера игры вообще долго оставалась своеобразным эталоном в европейской музыкальной культуре. Так, Ф. Шопен писал родным в Варшаву из Праги, 21 ноября 1830 года: «Кленгель, когда я ближе с ним познакомился, то есть когда сыграл ему свои концерты, сказал, что моя игра напоминает ему Фильда и что у меня редкостное туше, что он, конечно, много обо мне слышал, но все же никогда не ожидал, что я такой виртуоз. Это не были пустые комплименты, потому что он признался мне, что не любит льстить кому бы то ни было, ни принуждать себя к похвалам». И далее: «Я отнесся к Кленгелю так, как мало к кому в моей жизни: я действительно полюбил его, как если бы знал его уже лет тридцать» [31, с. 190].

2 Так, например, ноктюрн Фильда Си бемоль мажор, цитата из которого использована в одном из вариационных циклов Глинки, отличают близкие глинкинскому ноктюрну черты: трехчастность формы, при которой две темы первой части основаны на интонационной общности, средний раздел построен на новой, лирической теме, а кода опирается на музыкальный материал темы среднего раздела.
} 
ярким впечатлением от игры пианиста Поллини, исполнителя незаурядного таланта, итальянского знакомого Глинки. Стиль фортепианного исполнительства Поллини русский композитор высоко ценил, отмечая, что именно ему принадлежит открытие нового способа игры на фортепиано, при котором мелодия, окруженная пассажами, располагалась в среднем регистре и распределялась между двумя руками: тип знаменитой педальнообертоновой фактуры, характерной приметы бриллиантого стиля. Однако, примечательно то, что и за этим, сугубо фортепианным открытием, обнаруживается аура арфы: на самом деле, изобретение этого способа игры принадлежало знаменитому арфисту XIX века! Г. Риман считает, что знаменитый прием, ставший отличительной чертой стиля многих пианистов этого времени, например, С. Тальберга, изобрел арфист-виртуоз Э. Пэриш-Альварс [20, с. 1243]; Ф. Поллини, по всей видимости, первым применил его на фортепиано. Это выглядит убедительным; Н. Покровская отмечает общую романтическую тенденцию к обогащению звучания одного инструмента за счет использования средств другого, например, «заимствование у арфы фактуры из разложенных аккордов - арпеджио - и манеры исполнения аккордов в широком расположении - арпеджиато», или «подражание красоте bel canto в игре на скрипке и фортепиано» [18]. Глинка восхищался Поллини как музыкантом - доказательством тому его слова: «Pollini любил свое искусство искренно», т.е. наивысшая глинкинская оценка, ведь искренняя любовь к искусству всегда оставалась одним из важнейших критериев для русского композитора [4, с. 248]. «Несмотря на годы свои, - пишет в «Записках» Глинка, - [Поллини] играл еще даже самые многосложные пассажи своей музыки и до его времени никем не исполнимые, очень отчетливо и мягко, в противоположность почти всем другим maestro в Милане, которые нещадно били руками по клавишам» [4, с. 248]. Отчетливо и мягко - а значит, поллиниевская манера была близка фильдовской, гуммелевской, и тоже соответствовала условному глинкинскому исполнительскому эталону!

Подытожим. Три пианиста - Дж. Фильд, Й. Гуммель и Ф. Поллини сформировали глинкинское представление об эталонном звучании фортепиано, что со всей очевидностью проявится после итальянского путешествия. Однако и первый ноктюрн является утверждением художественных представлений композитора в области пианизма поисков уникального соединения индивидуализированно трактованной романтической просветленной образности и набора музыкальных средств, в полной мере отвечающих мировосприятию молодого Глинки. Смыслообразы первого ноктюрна связаны со значимыми для композитора 
впечатлениями предшествовавших лет, несмотря на то, что о пьесе и обстоятельствах ее сочинения в «Записках» ничего не сказано. Конец 20-х годов - взлет творческой активности композитора. Основанием становятся новые знакомства и общение, оказавшие влияние на окончательное формирование мировосприятия молодого Глинки: знакомство с князем С. Голицыным, камер-юнкером Е. Штеричем, общение с графом М. Виельгорским, бароном А. Дельвигом (посещение его салона), А. Пушкиным, М. Шимановской и др.

Ноктюрновая сфера Глинки рождается из присущих его характеру светлых гармоничных настроений любования и упоения жизнью. Она возникает также из смыслового пространства фильдовских ноктюрнов и фильдовского пианизма, приверженцем которого Глинка оставался всю жизнь. Индивидуальность трактовки ноктюрна определяется глинкинской находкой соединения просветленного образа с фильдовским туше, особенностей фактуры и мелодики с арфовым исполнительством, а также с ориентацией фортепиано на ее звучание. Такая специфика, зашифрованная в ноктюрновых эпизодах музыки Глинки разных жанров и сфер - камерно-инструментальной, фортепианной, ансамблевой значима для исполнительской трактовки его сочинений. Смысло-образы ноктюрна Глинки формируются на пересечении жанра (ноктюрн с ощутимым признаками жанров баркаролы, романса, ариозной кантилены, песни - без слов), художественного содержания (лирическисозерцательного, несколько меланхолического, просветленноидиллического), формы-схемы (опоры на классическую форму в синтезе с чертами трехчастности, решенной индивидуализированно) и инструментов для исполнения - взаимозамещающих, но и взаимно ориентированных на характер звучания друг друга. В этом смысле оговорка Глинки по поводу сочинения Вариаций на тему Моцарта - «для арфы $u$ фортепиано» - даже символична [4, с. 221].

Музыкальные образы ноктюрна Глинки отзываются почти интертекстуальными перекличками - не только с музыкой, но и с литературой, поэзией, эстетической мыслью европейского романтизма. Возникающие в едином смысловом пространстве романтизма, они становятся еще одним словом в тексте своего времени, утверждая собой «определенную „точку отсчета" рефлексии автора, его желания понять себя и окружающий мир на новой эмоционально-интеллектуальной волне, источник которой принадлежит другому автору, авторам, коллективному бессознательному» $[16$, с. 32$]$. Ведь память культуры - темы и образы разных времен, и 
узнаваемые в ней авторские голоса, символы своей эпохи, - то пространство смыслов, которое прочитывается в музыке Глинки.

1. Аверинцев С. Размышления над переводами Жуковского//Зарубежная поэзия в переводах В.А. Жуковского в двух томах. Т.2. М.: Радуга, 1985. На разных языках с параллельным русским текстом. $640 \mathrm{c}$.

2. Браудо Е.М. Всеобщая история музыки. Т.2. От начала 17 до серединь 19 столетия. М., 1930.

http://www.opentextnn.ru/music/epoch\%20/braudo/Bd.2.\%20XVII-

XIX\%20century/?id=2956 (дата обращчения: 12.03.2018).

3. Веселовский А.Н. Поэзия чувства и «сердечного воображсения». CПб., 1904. URL: http://dugward.ru/library/gukovskiy/veselovskiy_gukovskiy.html (дата обращения: 12.03.2018).

4. Глинка М.И. Полное собрание сочинений. Литературные произведения и переписка. М.: Музыка, 1973. Т. I: Творческие материаль. Биографические материальл. 483 c.

5. Глинка М.И. Полное собрание сочинений. Литературные произведения и переписка. М.: Музыка, 1975. Т. ІІА: Письма 1822-1853. Документыл. 415 с.

6. Глинка М.И. Полное собрание сочинений. Литературные произведения и переписка. М.: Музыка, 1977. Т. ІІБ: Письма 1854-1857. Письма Глинке. 397 с.

7. Глинка М.И. Полное собрание фортепианных сочинений. Л., 1952. T. IV. 442 c.

8. Загорный Н.Н. Фортепианное наследие М.И. Глинки//Глинка М.И. Полное собрание фортепианных сочинений. Л., 1952. Т. IV. С. VII-XV.

9. Зенкин К. Фортепианная миниатюра и пути музыкального романтизма. М.: Московская государственная консерватория им. П.И. Чайковского, 1997. 415 c.

10. Зимин П.Н. История фортепиано и его предшественников. - Bсе пианисты. URL: http://allpianists.ru/historyl.html.

11. История музыкальных инструментов: Appa//Art world (Грани искусства). URL: http://muzclassik.wordpress.com/.

12. Криницын А.Б. Тютчев и немечкий романтизм//Сравнительное литературоведение. Россия и Запад. М., 2008. C. 140-161. URL: https://istina.msu.ru/publications/article/40833323/(дата обращения: 12.03.2018).

13. Левашева О.Е. Михаил Иванович Глинка: монография. В 2 кн. М.: Музыка, 1988. Кн. 2. 352 с., с ил., нот. (Классики мировой музыкальной культуры).

14. Ливанова Т., Протопопов Вл. Глинка. Творческий путь: В 2 m. М.: Государственное музыкальное издательство, 1955. T.1. 404 с.

15. Музыкальная энциклопедия. М.: Советская энцииклопедия, Советский композитор/Под ред. Ю.В. Келдыма. 1973-1982. URL: http://dic.academic.ru/dic.nsf/enc_music/786/ (дата обращчения: 12.03.2018).

16. Муратова Е.Ю. Интертекстуальность как фактор смыслопорождения в поэтическом тексте//Вестник ВолГУ. Серия 2: Языкознание. 2012. №2 (16). URL: https://cyberleninka.ru/article/n/intertekstualnost-kak-faktor-smysloporozhdeniya-vpoeticheskom-tekste (дата обращения: 12.03.2018).

17. Пистон У. Оркестровка. Учебное пособие/[пер. с английского К.Н. Иванова]. М.: Советский композитор, 1990. 464 c.

18. Покровская Н.Н. История исполнительства на арфе: дисс. ... доктора искусствоведения : 17.00.02. Новосибирск, 2001. 453 c. URL: http://www.dissercat.com/ content/istoriya-ispolnitelstva-na-arfe (дата обращения: 12.03.2018). 
19. Природа в ранней лирике Кольриджа. URL: http://coleridge.narod.ru/ranlirik.htm (дата обращения: 12.03.2018).

20. Риман Г. Музыкальный словарь: Перевод с 5-го немецкого издания Б. Юргенсона / Пер. и все доп-я под ред. Ю. Энгеля. М., 1896. 1535 с.

21. Соллертинский И. Берлиоз. M., 1962. URL: http://alexkrm.narod.ru/papers/ Journalizm/MJ/sollert_berlios.htm (дата обращения: 12.03.2018).

22.Тимченко-Быхун И. Первая программная миниатюра М. Глинки «Прощальный вальс»: автобиографические смысль и итальянские музыкальные влияния// Музичне мистечтво і культура. Mиsic art and culture. Науковий вісник. Одеса: Одеська начіональна музична академія імені А.В. Нежданової, «Астропринт», 2014. Bun.20. C. 115-129.

23. Тимченко-Быхун И. Средоточие элегических смыслов фортепианного инструментализма М. Глинки: ноктюрн «Разлука» $и$ «Вальс-фантазия». Київ: Київський інститут музики ім. Р.М. Глієра, 2015. Вип. 51. с. 89-105.

24. Тимченко-Быхун И. Трилогия мазурок М. Глинки 1834-1835 годов и ее художественные смысль//Музичне мистеитво і культура. Music art and culture. Науковий вісник. Одеса: Одеська національна музична академія імені А. В. Нежданової, «Астропринт», 2015. Вип. 21. С. 33-47.

25. Тимченко-Быхун И. А. Диалог музыкального и вербального текстов смоленской фортепианной тетралогии М.И. Глинки «Привет Отчизне» и его художественнобиографические смыслы//Київське музикознавство. Вип. 34 . Київ: Київський інститут музики ім. Р.М. Глієра, 2014. С. 72-86.

26. Тургенев И. Призраки. URL: http://az.lib.ru/t/turgenew_i_s/text_1260.shtml (дата обращения: 12.03.2018).

27. Тылико С.В., Мамаев С.Г. Странствия Глинки. Комментарий к «Запискам». К., 2000. Ч. І.: Украина. 221 с.

28. Тышко С. В., Мамаев С. Г. Странствия Глинки. Комментарий к «Запискам». Киев : Задруга, 2002. Ч. ІІ: Глинка в Германии, или Апология романтического сознания. $509 \mathrm{c}$.

29. Чулаки М.И. Инструменты симфонического оркестра. М.: Государственное музыкальное издательство, 1972. Изд. 3-е, переработанное. 176 с.

30. Шлифштейн С. К поэзии реальной жизни. О романсной лирике Глинки//Избранные статьи. М.: Советский композитор, 1977. С. 233-260.

31. Шопен Ф. Письма: В 2 т. М.: Музыка, 1976. Т. 1. 527 с.

32. Эничиклопедический словарь Ф.А. Брокгауза и И.А. Ефрона. С.-Пб.: Брокгауз-Ефрон 1890-1907. URL: http://www.medicine-encyclopedia.info/brokgause/Jeolova-arfa45542.html (дата обращения: 12.03.2018).

33. Энииклопедия символов. М.: ООО «Издательство АСТ», Харьков «Торсинг», 2003. 591, [1] с.: ил.

34. Эстетика раннего франиузского романтизма/Сост., вступ. статья и коммент. В.А. Мильчиной; Пер. с фр. М.: Искусство, 1982. 480 с. (История эстетики в памятниках и документах).

35. Яковкина Н.И. Русская литература в первой половине ХІХ века. История русской культуры XIXвек. URL: http://www.plam.ru/hist/istorija_russkoi_kultury_xix_vek/p2.php (дата обращения: 12.03.2018). 


\section{References}

1. Averintsev, S. (1985). Reflections on translations of Zhukovsky [Razmyishleniya nad perevodami Zhukovskogo]. Foreign poetry in the translations of V.A. Zhukovsky [Zarubezhnaya poeziya v pere-vodah V.A. Zhukovskogo] in two volumes. V.2. M.: Raduga. 640 p.

2. Braudo, E.M. (1930). The general history of music. T.2. From the early 17th to the middle of the 19th century.[Vseobschaya istoriya muzyiki. T.2. Ot nachala 17 do seredinyi 19 stoletiya]. M. Available at: http://www.opentextnn.ru/music/epoch\%20/braudo/Bd.2.\%20XVIIXIX\%20century/?id=2956 [Accessed: 12.03.2018].

3. Veselovskiy, A.N. (1904). Poetry of feeling and «imagination of the heart» [Poeziya chuvstva $i$ «serdechnogo voobrazheniya»]. SPb. Available at: http://dugward.ru/library/gukovskiy/veselovskiy_gukovskiy.html [Accessed: 12.03.2018].

4. Glinka, M.I. (1973). Full composition of writings. Literary works and correspondence. [Polnoe sobranie sochineniy. Literaturnyie proizvedeniya i perepiska]. M.: Muzyika. V.I: Creative materials. Biographical materials [Tvorcheskie materialyi. Biograficheskie materialyi]. 483 p.

5. Glinka, M.I. (1975). Full composition of writings. Literary works and correspondence. [Polnoe sobranie sochineniy. Literaturnyie proizvedeniya i perepiska] M.: Muzyika. V. IIA: Letters of 1822-1853. Documentation [Pisma 1822-1853. Dokumentyi]. 415 p.

6. Glinka, M.I. (1977). Full composition of writings. Literary works and correspondence [Polnoe sobranie sochineniy. Literaturnyie proizvedeniya i perepiska]. M.: Muzyika. V. IIB: Letters of 1854-1857. Letters from Glinka [Pisma 1854-1857. Pisma Glinke]. 397 p.

7. Glinka, M.I. (1952). Complete collection of piano works [Polnoe sobranie fortepiannyih sochineniy]. L., V.IV. 442 p.

8. Zagornyiy, N.N. (1952). Piano works of M.I. Glinka//Glinka M.I. Complete collection of piano works [Fortepiannoe nasledie M.I. Glinki//Glinka M.I. Polnoe sobranie fortepiannyih sochineniy]. L., V. IV.p. VII-XV.

9. Zenkin, K. (1997). Piano miniature and the path of musical romanticism [Fortepiannaya miniatyura i puti muzyikalnogo romantizma]. Moscow: Moscow State Conservatory P. I. Tchaikovsky. 415 p.

10. Zimin, P.N. The history of the piano and its predecessors [Istoriya fortepiano i ego predshestvennikov]. - All pianists [Vse pianistyi]. Available at: http://allpianists.ru/history1.html [Accessed: 12.03.2018].

11. History of musical instruments [Istoriya muzyikalnyih instrumentov]: Arfa. Art world Edge of art [Grani iskusstva]. Available at: http://muzclassik.wordpress.com/ [Accessed: 12.03.2018].

12. Krinitsyin, A.B. (2008). Tiutchev and German Romanticism. Comparative literary criticism. Russia and the West. [Tyutchev $i$ nemetskiy romantizm. Sravnitelnoe literaturovedenie. Rossiya $i$ Zapad]. Moscow, p.140-161. Available at: https://istina.msu.ru/publications/article/40833323/ [Accessed: 12.03.2018].

13. Levasheva, O.E. (1988). Mikhail Ivanovich Glinka: a monograph [Mihail Ivanovich Glinka: monografiya]. In 2 books. Moscow: Muzyika. Book 2. 352 p.

14. Livanova, T., Protopopov, Vl. (1955). Glinka. Creative way [Glinka. Tvorcheskiy put] In 2 volumes. Moscow: State Music Publishing House. V.1. 404 p.

15. The musical encyclopedia [Muzyikalnaya entsiklopediya]. Soviet Encyclopedia, Soviet composer. Edited by Yu.V. Keldysh. Moscow. 1973-1982. Available at: http://dic.academic.ru/dic.nsf/enc_music/786/ [Accessed: 12.03.2018]. 
16. Muratova, E.Yu. (2012). Intertextuality as a factor of meaningfulness in a poetic text [Intertekstualnost kak faktor smyisloporozhdeniya $v$ poeticheskom tekste]. Bulletin of Volgograd State University [Vestnik VolGU]. Series 2: Linguistics \#2 (16). Available at: https://cyberleninka.ru/article/n/intertekstualnost-kak-faktor-smysloporozhdeniya-vpoeticheskom-tekste [Accessed: 12.03.2018].

17. Piston, U. (1990). Orchestration. Textbook [Orkestrovka. Uchebnoe posobie]. Trans. from English K.H. Ivanova. Moscow: Soviet composer. 464 p.

18. Pokrovskaya, N.N. (2001). The history of the harp performance. [Istoriya ispolnitelstva na arfe]. Thesis for the competition uch. Doctor of Arts. Novosibirsk, 2001. The code of the VAK: 17.00.02. $453 \mathrm{p}$. Available at: http://www.dissercat.com/content/istoriyaispolnitelstva-na-arfe [Accessed: 12.03.2018].

19. Nature in the early lyrics of Coleridge [Priroda $v$ ranney lirike Kolridzha]. Available at: http://coleridge.narod.ru/ranlirik.htm [Accessed: 12.03.2018].

20. Riman, G. (1896). Musical dictionary: Translation from the fifth German edition of B. Jurgenson. Translation and all additions edited by J. Engel. [Muzyikalnyiy slovar: Perevods 5-go nemetskogo izdaniya B. Yurgensona. Perevod i vse dopolneniya pod redaktsiey Yu. Engelya]. Moscow, 1535 p.

21. Sollertinskiy, I. (1962). Berlioz. Moscow. Available at: http://alexkrm.narod.ru/papers/Journalizm/MJ/sollert_berlios.htm [Accessed: 12.03.2018].

22. Timchenko-Byihun, I. (2014). The first mini program of M. Glinka «Farewell Waltz»: autobiographical meanings and Italian musical influences [Pervaya programmnaya miniatyura M. Glinki «Proschalnyiy vals»: avtobiograficheskie smyislyi $i$ italyanskie muzyikalnyie vliyaniya]. Music art and culture. Scientific Herald. Odessa: Odessa National Musical Academy named after A.V. Nezhdanova, «Astropry`nt». Issue 20. p. 115-129.

23. Timchenko-Byihun, I. (2015). The focus of the elegiac meanings of M. Glinka's piano instrumentalism: the Nocturne of Separation and Waltz-Fantasy [Sredotochie elegicheskih smyislov fortepiannogo instrumentalizma M. Glinki: noktyurn «Razluka» $i$ «Vals-fantaziya»]. Kyiv: R. Glier Kyiv Institute of Music. Issue 51.p. 89-105.

24. Timchenko-Byihun, I. (2015). The trilogy of M. Glinka's mazurkas of 1834-1835 and its artistic meanings [Trilogiya mazurok M. Glinki 1834-1835 godov i ee hudozhestvennyie smyislyi]. Music art and culture. Scientific Herald. Odessa: Odessa National Musical Academy named after A.V. Nezhdanova «Astropry `nt». Issue 21. p. 33-47.

25. Timchenko-Byihun, I.A. (2014). Dialogue of musical and verbal texts of Smolensk piano tetralogy M. I. Glinka «Hello to the Fatherland» and his artistic and biographical meanings [Dialog muzyikalnogo i verbalnogo tekstov smolenskoy fortepiannoy tetralogii M.I. Glinki «Privet Otchizne» $i$ ego hudozhestvenno-biograficheskie smyislyi]. Kyiv: R. Glier Kyiv Institute of Music. Issue 34. p. 72-86.

26. Turgenev I. Ghosts [Prizraki]. Available

at: http://az.lib.ru/t/turgenew_i_s/text_1260.shtml [Accessed: 12.03.2018].

27. Tyishko, S.V., Mamaev, S.G. (2000). Wanderings of Glinka. Comment on the «Notes» [Stranstviya Glinki. Kommentariy $k$ «Zapiskam»]. Kyiv, Ch. I.: Ukraina, 221 p.

28. Tyishko, S.V., Mamaev, S.G. (2002). Wanderings of Glinka. Comment on the "Notes». Ch. II: Glinka in Germany, or the Apology of Romantic Consciousness [Stranstviya Glinki. Kommentariy $k$ «Zapiskam». Ch. II: Glinka v Germanii, ili Apologiya romanticheskogo soznaniya]. Kyiv: Zadruga. 509 p.

29. Chulaki, M.I. (1972). Instruments of the symphony orchestra. [Instrumentyi simfonicheskogo orkestra]. 3rd edition, revised. Moscow: State Musical Publishing House, 176 p. 
30. Shlifshteyn, S. (1977). To the poetry of real life. About Glinka's romance lyrics. Selected articles [K poezii realnoy zhizni. Oromansnoy livike Glinki. Izbrannyie stati]. Moscow: Soviet composer, p. 233-260.

31. Chopin, F. (1976). Letters: in 2 volumes [Pisma: V 2 t.]. Moscow: Muzyika. V. 1. 527 p.

32. The Brockhaus and Efron Encyclopedic Dictionary [Entsiklopedicheskiy slovar F.A. Brokgauza i I.A. Efrona]. St. Petersburg: Brockhaus-Efron 1890-1907. Available at: http://www.medicineencyclopedia.info/brokgause/Jeolova-arfa-45542.html [Accessed: 12.03.2018].

33. Encyclopedia of symbols [Entsiklopediya simvolov]. Moscow: OOO «Izdatelstvo AST», Harkov «Torsing», 2003. 591, [1] p.: illustrations.

34. Aesthetics of Early French Romanticism [Estetika rannego frantsuzskogo romantizma] Moscow: Iskusstvo, 1982. 480 p. (History of aesthetics in the memory and documents).

35. Yakovkina, N.I. Russian literature in the first half of the XIX century. History of Russian culture XIX century [Russkaya literatura v pervoy polovine XIX veka. Istoriya russkoy kulturyi XIX vek]. Available at: http://www.plam.ru/hist/istorija_russkoi_kultury_xix_vek/p2.php [Accessed: 12.03.2018]. 